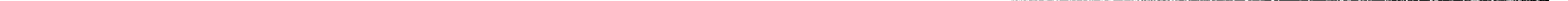




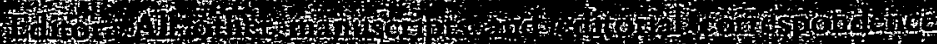

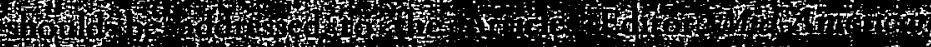

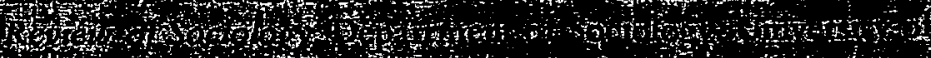

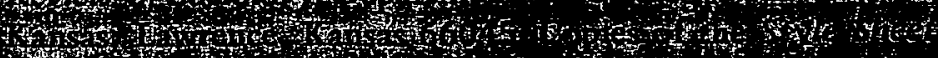

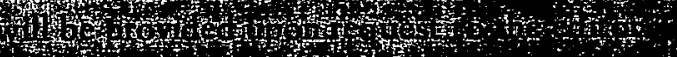

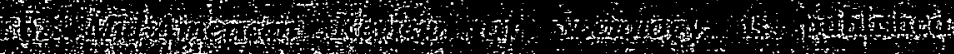

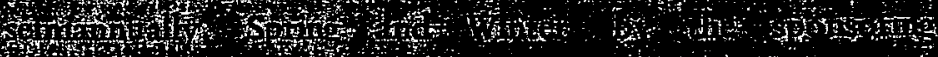
(7) Whot

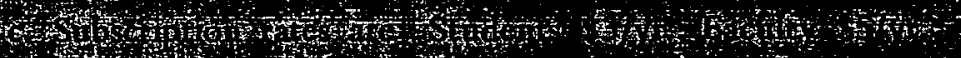

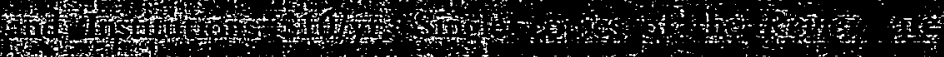

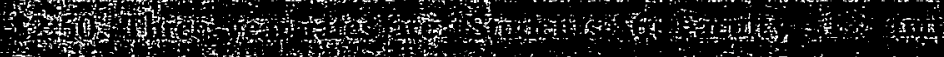

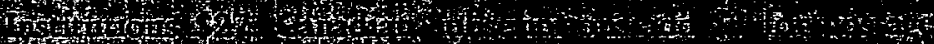

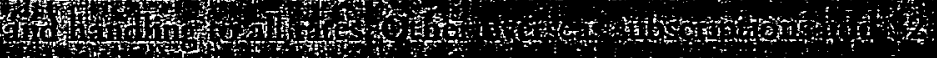

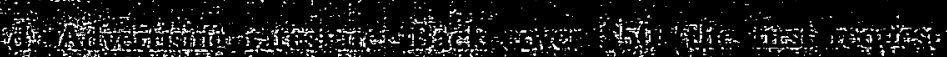

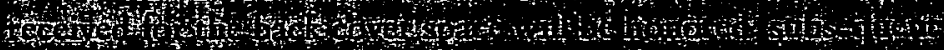

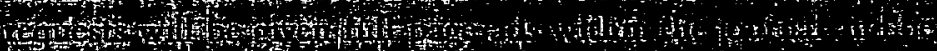

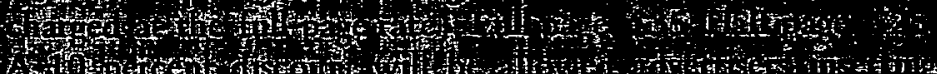

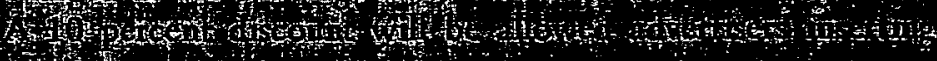

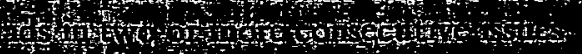

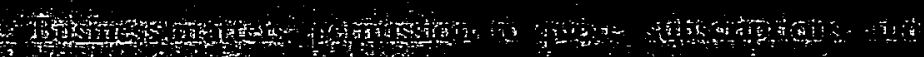

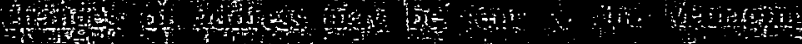

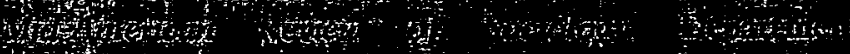

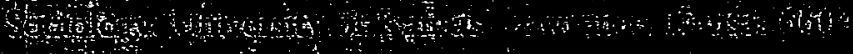

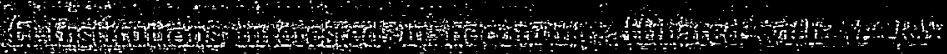

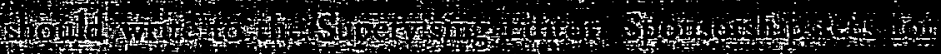
Ho

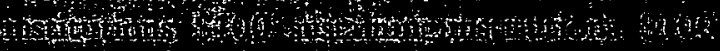

a.

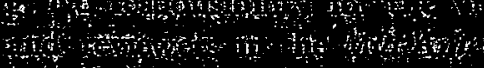

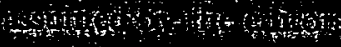

WAYNE DERX Managing Editor

\section{ALAN JOHNSON}

Consulting Editor

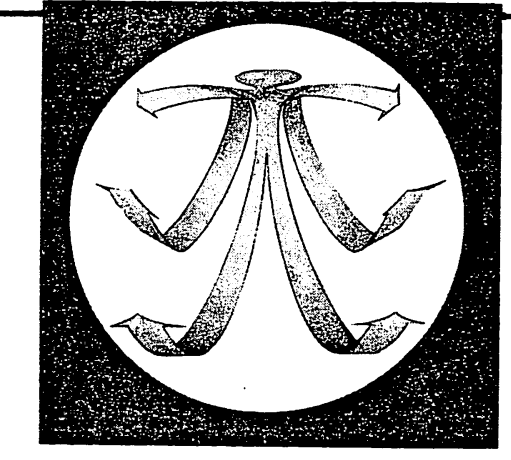

HERBERT HAINES

Editor-in-Chief

\section{CYNTHIA FLYNN}

Supervising Editor

Edited at the Department of Sociology, University of Kansas

Associate Editors

Dr. ROBERT BILBY (pro tem)

University of Wisconsin, $\mathrm{La}$ Crosse

DAVE O'DONNELL

University of Nebraska, Lincoln

LARRY IRONS

Washington University

CHRISTINA MONTGOMERY

University of Nebraska, Omaha

$$
\begin{gathered}
\text { DANTE OLIVERI } \\
\text { Ohio University }
\end{gathered}
$$

RICHARD WELLS

Texas A \& M University

TERESA WARNER

Hastings College

WAYNE WHITE

Kansas State University

RENEE ZIMMERMAN

Wichita State University

Staff

DAVID DICKENS, GREGORY JOHNSON, GINI NELSON, PRUDENCE SIEG, NOVELA PERRIN, HARLAND PRECHEL, ROBERT RUCKER 


\section{CONTENTS}

\section{ARTICLES}

Reflections on the Paradigmatic Status of Sociology

Role Changes Associated with Widowhood Among Middle and Upper-Class Women

Toward a Social Psychology of Food Use Peggy A. Shifflett and Kenneth L. Nyberg

Labeling and Oppression: Witchcraft in Medieval Europe

\section{Notes and Comments}

Sociological Implications of the Habermas-Related Second Generation of the Frankfurt School:

A Bibliographic Essay

A Critical Review and Assessment of the Sociology of Law

\section{Book Reviews}

Introduction to Sociology

Mavis Hiltunen Biesang and John Biesang.

Reviewed by Muriel Faltz Lembright

Labor Economics: A Guide to Information Sources Ross E. Azevado (ed.). Reviewed by Parviz Piran

Deviant Behavior: An Interactionist Approach Erich Goode. Reviewed by Jane C. Ollenburger

The Dual Vision: Alfred Schutz and the Myth of of Phenomenological Social Science

Robert Gorman. Reviewed by David R. Dickens
Sociology of Childhood

Marvin R. Koller and Oscar W. Ritchie.

Reviewed by Starla D. Fitch

One Potato, Two Potato: The Folklore of

American Children

Mary Knapp and Herbert Knapp.

Reviewed by Melissa Nuckolls
Mid-American Review of Sociology Sponsors

\section{HASTINGS COLLEGE}

Department of Sociology

\section{UNIVERSITY OF KANSAS}

Department of Sociology*

\section{KANSAS STATE UNIVERSITY}

Department of Sociology, Anthropology and Social Work*

\section{UNIVERSITY OF NEBRASKA at LINCOLN}

Department of Sociology*

\section{UNIVERSITY OF NEBRASKA at OMAHA}

Department of Sociology

\section{OHIO UNIVERSITY}

Department of Sociology and Anthropology

\section{TEXAS A\&M UNIVEERSITY}

Department of Sociology and Anthropology*

Department of Rural Sociology*

\section{WASHINGTON UNIVERSITY}

Department of Sociology*

WICHITA STATE UNIVERSITY

Department of Sociology

UNIVERSITY OF WISCONSIN at LA CROSSE

Department of Sociology and Anthropology

*Department offering a $\mathrm{Ph} . \mathrm{D}$. program 